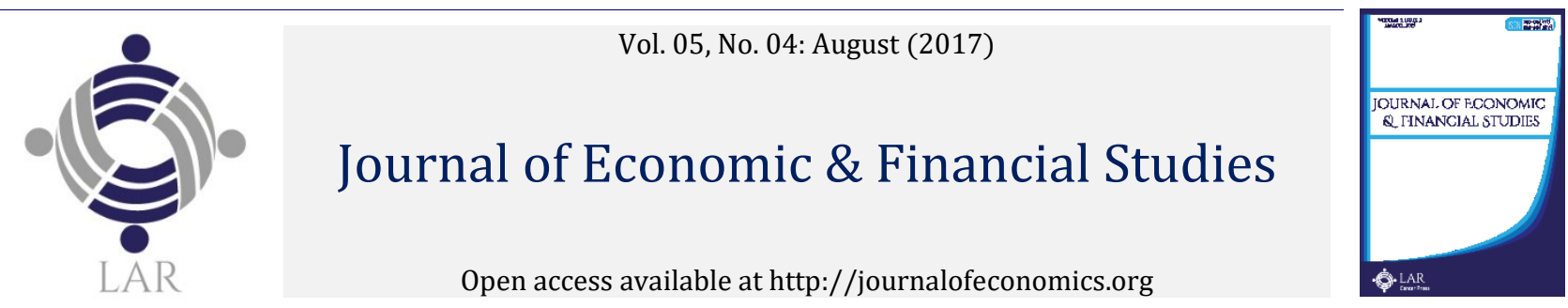

\title{
Socio-economy and stock market volatility
}

\author{
Md. Sharif Hossain ${ }^{a^{*}}$, Md. Thasinul Abedin ${ }^{\mathrm{b}}$ \\ a Accounting \& Information Systems, University of Dhaka, Dhaka-1000. \\ b Accounting \& Information Systems, University of Dhaka, Dhaka-1000. \\ *Corresponding author's email address: sharif_hossain0465@yahoo.com
}

\section{A R T I C LE INF O}

Received: 12-07-2017

Accepted: 02-08-2017

Available online: 10-08-2017

Keywords:

Domestic Investment;

Foreign Exchange Rate Volatility;

Strike and Blockades;

S \& P 500 Index Volatility;

VAR Model.

JEL Classification:

$\mathrm{C} 01$; C02 ; C22 ; D53 ; E22.

\begin{abstract}
A B S T R A C T
We evaluate how stock market return volatility behaves with respect to socioeconomic factors namely- interest rate volatility, foreign exchange rate volatility, S \&P 500 index volatility, broad money supply volatility, per capita GDP, domestic investment, industry value addition, tertiary level of education, urbanization, and strike and blockades using time series data from 1976-2015. We find that interest rate volatility has significant positive impact on stock market return volatility where broad money supply volatility, foreign exchange rate volatility, tertiary level of education, and domestic investment have significant negative impact on stock market volatility based on stepwise regression. Therefore, increase in tertiary level of education and domestic investment makes the stock market more stable. From the estimated result of VAR model, results show no short run causality among these variables.
\end{abstract}

(C) 2017 The Authors. This is an open access article under the terms of the Creative Commons Attribution License 4.0, which allows use, distribution and reproduction in any medium, provided the original work is properly cited.

\section{Introduction}

Stock market conduits the savings of people to efficient investments expediting economic growth and fueling the development vehicle. Therefore, as an economic institution, the stock market plays a major role in enhancing the efficiency of capital formation and allocation. Thus, the overall development of the economy is a function of how well the stock market performs. Empirical evidence has shown that the development of a capital market is essential for economic growth (Ashaolu and Ogunmuyiwa, 2011). However, stock market volatility may be an impediment in this process especially in a frontier economy like Bangladesh where high volatility in stock prices may lead to erosion of capital from the market. What drives excessive volatility in stock market is becoming a continued dialogue among researchers, academics, and market analysts. Volatility refers to unexpected movement in price due to unexpected events and rumors. As a result, the stock market may develop an unanticipated behavior that may puzzle the investors frequently.

Many studies have found that volatility in stock markets is affected by several macroeconomic factors, namely- interest rates, broad money supply, inflation rate, foreign currency movements, industrialization, domestic investment, etc. Apart from those factors, urbanization, level of education, and strike and blockades as social factors may affect the stock market volatility.

Even though volatility seems to inhibit sustainable development of the stock markets, for a number of countries capital market development has been supplemented by increased volatility (Wei, 2005). It may be assumed that the absence of effective and efficient oversight over the stock market is working as a major obstacle to the healthy development of the stock market. The volatility of the securities market is also associated with governance problems of the market. Market regulators all over the world consider market bubbles exhibiting 
"irrational exuberance" to have potential for economic disruptions and distortions. Besides, the perception of speculative behavior works against creating trust and a sense of fairness in financial markets. When combined with allegations of market manipulations, insider trading, and outright scams, the speculative nature of the market can be a serious impediment to capital formation, and efficient functioning of the financial markets (Krishnamurti et. al., 2003)

Therefore, a common question is usually raised by investors, researchers, and analysts: What are the key determinants of stock market volatility? Do social factors affect stock market volatility at all apart from macroeconomic factors or are macroeconomic factors simply affecting stock market volatility? To give the answer of those questions, this paper has tried to discover how stock market return volatility in Bangladesh is affected by the socioeconomic factors namely- foreign exchange volatility, Standard and Poor 500 Index volatility, interest rate volatility, money supply volatility, domestic investment, economic growth, industry value addition, strike and blockades, tertiary level of education, and rate of urbanization.

The study will help to gather knowledge on the relation between stock market return volatility and socioeconomic variables as it is crucial to investors in the equity market as well as policy makers to redesign monetary policies and other macroeconomic policies. For investors, discovering the impact of socioeconomic variables on stock market return volatility could help them forecast stock prices movements appropriately. If the movement of socioeconomic variables can be used as reliable indicators for stock market volatility, it can also help them in managing their investment portfolios. Meanwhile, from the macroeconomic point of view, it is important for policymakers to be able to identify relationships between stock market return volatility and macroeconomic variables' movement. If stock market volatility leads macroeconomic variables, policymakers could use stock market volatility as a leading indicator to predict future macroeconomic variables' movement. On the other hand, if stock market volatility does not lead macroeconomic variables, it is not wise for a policy maker to focus on stock market volatility. Therefore, it is worthwhile to determine whether macroeconomic variables can explain stock market volatility or not. From a social perspective, the higher the level of education, the more people will be more willing to invest in the stock market. They will make prudential decisions before going into to the stock market. The higher the rate of urbanization, the more concerned the people will be about investment in the stock market, and many people might be attracted to come into the stock market. However, economy's strike and blockades may interrupt the investors' involvement in stock market.

\section{Literature review}

Several studies have been conducted to discover the impact of macroeconomic factors on stock market volatility or stock market return volatility. For example-- Fama and Schwert (1977) have found a direct linkage between macroeconomic volatility and stock market return volatility. Fama (1981) has deduced that a reverse relationship prevails between stock returns and inflation and also claimed that an increase in real activity would spur the demand for money which as a result generates an upward relationship between stock market returns and money supply. Schwert (1989) has discovered a positive association between stock market volatility and macroeconomic indicators' volatility (See also: David and Kutan, 2003). Liljeblom and Stenius (1997) have found that variations in conditional stock market volatility are associated with conditional macroeconomic volatility (inflation, industrial production, and money supply) (See also: Morelli, 2002). Engle and Rangel (2005) have concluded that volatility in macroeconomic variables (economic growth, inflation, and short-term interest rate) are the key independent variables that swell out unconditional stock market volatility.

Chowdhury and Rahman (2004) have investigated the linkage between the volatility of macroeconomic variables and stock return volatility. They have recapitulated that macroeconomic volatility significantly causes stock market volatility. However, Oseni and Nwosa (2011) have not found any evidence on the causal relationship between stock market volatility and the volatility in interest rate and inflation rate but Chinzara (2011) have found that macroeconomic uncertainty significantly affects stock market volatility (See also: Okoli, 2012).

Kadir et al. (2011) have examined the impact of interest rate volatility and exchange rate volatility on stock return volatility. Their results suggest that stock return volatility is negatively related to interest rate and positively related to exchange rate but both of these relationships are insignificant. However, Zakaria and Shamsuddin (2012) have found little sustenance on the presence of the relationship between stock market volatility and macroeconomic volatility. They claimed that interest rate volatility Granger-causes stock market volatility and only money supply volatility is significantly associated with stock market volatility. Yaya and Shittu (2010) have observed that exchange rate and inflation have a significant influence on the volatility of stock returns. Moreover, Aliyu (2012) have found that inflation rate and its 3-month average have significant effects on stock market volatility.

Almost all of the above mentioned literatures are based on how macroeconomic factors affect stock return volatility or stock market volatility. Therefore, a research gap prevails: Whether social factors (namely the level of education, rate of urbanization, and strike and blockades) affect stock market return volatility or not. Therefore, the main objective of this study is to discover how social factors along with macroeconomic factors affect stock market return volatility. It is also notable that no one in Bangladesh has conducted the study to discover the impact of social factors on stock market return volatility. 


\section{Data source and descriptive statistics}

To conduct the study, data have been collected from several sources. For example market return (MRET) ${ }^{1}$ has been calculated from market capitalization which has been collected from Dhaka Stock Exchange. Tertiary level of education (TLE) has been collected from the Statistical Year Book of Bangladesh. Money supply (M2), domestic investment as percentage of GDP (DINV), per capita GDP (PGDP), industry value addition (INDVA), foreign exchange rate (FER) (BDT/USD), and lending interest rate (LIR) have been collected from the World Bank Development Indicators. S\&P 500 index (SNP500) has been collected from the Bloomberg International terminal. The number of days of strike and blockades (HAR) has been collected from daily newspaper, research papers, and reports. A few descriptive statistics are given below in Table 1.

Table 1: Descriptive statistics

\begin{tabular}{lrrrrrrr}
\hline Variables & Minimum & Maximum & Mean & STDEV & CV & Skewness & Kurtosis \\
\hline MRET (\%) & -60.3476 & 95.8572 & 22.8772 & 33.3419 & 145.7429 & 0.2545 & 0.0632 \\
DINV & 14.8580 & 40.5091 & 22.8317 & 5.1408 & 22.5160 & 1.0227 & 2.4085 \\
FER(BDT/USD) & 15.0161 & 81.8627 & 45.3676 & 21.0215 & 46.3360 & 0.1536 & -1.2314 \\
SNP500 & 95.1000 & 2058.9 & 783.0403 & 594.5672 & 75.9306 & 0.4756 & -0.9122 \\
UR & 10.7010 & 34.2770 & 22.3968 & 6.2868 & 28.0700 & 0.1452 & -0.7603 \\
M2 (mn BDT) & 17154.4 & 9778287 & 1715358.2 & 2542014.81 & 148.1915 & 1.8597 & 2.6973 \\
HAR & 1.0000 & 172.0000 & 21.3250 & 32.1171 & 150.6077 & 3.3094 & 12.6388 \\
PGDP (USD) & 128.9425 & 1211.7020 & 424.2670 & 262.9987 & 61.9890 & 1.4615 & 1.6117 \\
LIR & 10.3992 & 16.0000 & 13.0312 & 1.6155 & 12.3968 & 0.4404 & -0.6501 \\
TLE & 25034 & 1382216 & 277263.325 & 404388.782 & 145.8501 & 1.7174 & 1.5826 \\
INDVA (mn BDT) & 21708.36 & 4067108 & $825,584.6$ & 1038763 & 125.8215 & 1.7380 & 2.3517 \\
\hline
\end{tabular}

Note: STDEV stands for Standard Deviation.

From the descriptive statistics of this data, it can be concluded that MRET, DINV, FER, SNP500, UR, M2, PGDP, LIR, TLE, and INDVA have a platykurtic distribution. HAR has a laptokutic distribution. All variables have a positively skewed distribution. Variables- MRET, M2, HAR, TLE, and INDVA have more variation (highest CV) than the other variables.

\section{Econometric methodology}

First, this paper applies unit root tests to check whether each variable has unit root problems or not. If MRET, M2, LIR, FER, and SNP500 are integrated or order one (I(1)), ARIMA(p, d, q) model would be used to calculate volatility of MRET, M2, LIR, FER, and SNP500 otherwise ARMA(p,q) model would be used. After calculation of volatility for MRET, M2, LIR, FER, and SNP500, again unit root tests will be applied to check whether volatility of each variable contains unit root problems or not. If the volatility of each variable contains unit root problems along with other variables-DINV, UR, PGDP, TLE, and INDVA and all variables are integrated of order one (I(1)) or there exists mixed orders of variables (some are stationary at level form $(\mathrm{I}(0)$ ) and some are stationary at first difference form (I(1))), then tests of co-integration (Johansen and Juiselius 1990) or Bound testing Approach(Pesaran and Pesaran, 1997; Pesaran and Shin, 1999; Pesaran et al., 2001)) will be applied to check whether there exists long run relationship among the variables or not. If a long run relationship exists as suggested by the tests of cointegration, then the VECM model will be estimated to investigate short run and long run causality. Finally, after causality analysis, short run and long run equations would be estimated. If there exists no cointegrating relationship suggested by the tests of cointegration, then simply a short run equation along with a VAR model will be estimated for conclusions and policy implications. All variables except MRET, M2, SNP500, LIR, and FER will be expressed in logarithmic forms.

\subsection{Unit root test}

To check whether unit root problems exist or not, the ADF test with trend and intercept, with intercept only, and without trend and intercept will be applied. The forms of the ADF test with trend and intercept, with intercept only, and without trend and intercept are given below-

$$
Z_{\mathrm{t}}=K_{0}+K_{1} t+\delta Z_{t-1}+\sum_{j=1}^{m} \Phi_{j} \Delta Z_{t-j}+u_{t}
$$

The form of ADF test with only intercept is given below:

$$
\mathrm{Z}_{\mathrm{t}}=K_{0}+\delta Z_{t-1}+\sum_{j=1}^{m} \Phi_{j} \Delta Z_{t-j}+u_{t}
$$

\footnotetext{
${ }^{1}$ MRET $=\left(\frac{\text { Market Capitalization }_{\mathrm{t}}}{\text { Market Capitalization }_{\mathrm{t}-1}}-1\right) \times 100$
} 
The form of ADF test without intercept and trend is given below:

$$
Z_{\mathrm{t}}=\delta Z_{t-1}+\sum_{j=1}^{m} \Phi_{j} \Delta Z_{t-j}+u_{t}
$$

Here, $\mathrm{Z}$ is the variable under investigation. The variable is of $\mathrm{I}(1)$ if $\delta=0$. Appropriate lag length of equation (1), (2), and (3) would be selected by the SBIC criteria. Apart from the ADF test, the PP test will be applied to get an overwhelming conclusion (robustness check). The unit root test results have been provided in Appendix Table-1 (at level form) and in Appendix Table-2(at first difference form). From the tests results, it can be concluded that all variables of are of I(1) suggested by ADF test and PP test except MRET which in stationary at level form or integrated of order zero (I(0)).

\section{2 $\operatorname{ARMA}(\mathrm{p}, \mathrm{q})$ and $\operatorname{ARIMA}(\mathrm{p}, \mathrm{d}, \mathrm{q})$ models}

If the variable under investigation is stationary, then volatility will be estimated under the following $\operatorname{ARMA}(p, q)$ model:

$$
\mathrm{X}_{\mathrm{t}}=\varphi_{0}+\sum_{\mathrm{i}=1}^{\mathrm{p}} \varphi_{\mathrm{i}} \mathrm{X}_{\mathrm{t}-\mathrm{i}}+\sum_{\mathrm{j}=1}^{\mathrm{q}} \lambda_{\mathrm{j}} \varepsilon_{\mathrm{t}-\mathrm{j}}+\varepsilon_{\mathrm{t}} \text {, where, } \varepsilon_{\mathrm{t}} \sim \mathrm{N}\left(0, \sigma_{\mathrm{t}}^{2}\right) \text {. }
$$

If variable under investigation is not stationary then volatility will be estimated under the following $\operatorname{ARIMA}(p, d, q)$ model:

$$
\Delta^{\mathrm{d}} \mathrm{X}_{\mathrm{t}}=\varphi_{0}+\sum_{\mathrm{i}=1}^{\mathrm{p}} \varphi_{i} \Delta^{\mathrm{d}} \mathrm{X}_{\mathrm{t}-\mathrm{i}}+\sum_{\mathrm{j}=1}^{\mathrm{q}} \lambda_{\mathrm{j}} \varepsilon_{\mathrm{t}-\mathrm{j}}+\varepsilon_{\mathrm{t}}, \text { where, } \varepsilon_{\mathrm{t}} \sim \mathrm{N}\left(0, \sigma_{\mathrm{t}}^{2}\right)
$$

Where $\mathrm{X}$ is the variable under investigation and $\Delta$ stands for the difference of the variable and $\mathrm{d}=1$ indicates first difference form of the variable X. $\sigma_{t}^{2}$ is the estimated volatility either from equation (4) or (5). After estimation of volatility either from equation (4) or (5), again unit root test will be applied to check whether the logarithm of volatility contains unit root problems or not. Let's assume the volatility of MRET, FER, LIR, M2, and SNP500 are- $\sigma_{M R E T}^{2}, \sigma_{F E R}^{2}, \sigma_{L I R}^{2}, \sigma_{M 2}^{2}$, and $\sigma_{S N P}^{2}$. The best model (most economic model) for ARMA(p,q) or $\operatorname{ARIMA}(p, d, q)$ has been selected based on lowest value of AIC and SBIC. The estimated result of equation (4) and (5) has been provided in Table-4 and unit root test results of volatility have been provided in Table-5. From Table5 , it can be concluded that all variables are integrated of order zero ( I(0)).

Since the dependent variable $\ln \sigma_{\text {MRET }}^{2}$ is integrated of order zero (I(0)) along with other independent variables- $\ln \sigma_{F E R}^{2}, \ln \sigma_{\text {LIR }}^{2}, \ln \sigma_{M 2}^{2}$, and $\ln \sigma_{S N P}^{2}$. Later, a bound testing approach (Pesaran and Shin, 2001) for co-integration has been applied and there is no cointegrating relationship among the variables. The details of this approach has been avoided here. Therefore, all the variables will not move together in the long run.

Volatility of stock market return, lending interest rate, S\&P 500 index, money supply, and foreign exchange rate has been given in Figure-1(a), 1(b), 1(c), 1(d), and 1(e).

Table 2: ARMA(p,q) / ARIMA (p,d,q) model selection summary

\begin{tabular}{llrr}
\hline Variables & ARMA $(\mathrm{p}, \mathrm{q}) /$ ARIMA $(\mathrm{p}, \mathrm{d}, \mathrm{q})$ & \multicolumn{2}{r}{ Lowest Value } \\
\hline MRET & & AIC & SBIC \\
FER & ARMA $(1,2)$ & 6.6850 & 6.8556 \\
LIR & ARIMA $(1,1,0)$ & 1.4253 & 1.5115 \\
M2 & ARIMA $(1,1,0)$ & -0.5632 & -0.4770 \\
SNP500 & ARIMA $(1,1,1)$ & 17.0764 & 17.2057 \\
\hline
\end{tabular}

From Figure-1(a), 1(b), 1(c), 1(d), and 1(e), it can be said that money supply exhibits sharp volatility after 2000 and has continued up to 2002 and again exhibits volatility after 2008 and has continued up to 2012 , foreign currency (BDT/USD) exhibits excess volatility after 2004 and has continued up to 2005 and again exhibits excess volatility after 2011 and has continued up to 2012. It can also be said that there is a negative relationship between stock market return volatility and S\&P 500 index volatility, between stock market return volatility and money supply volatility, and between foreign exchange rate volatility and stock market return volatility. 
Figure 1 (a): Volatility of stock market return

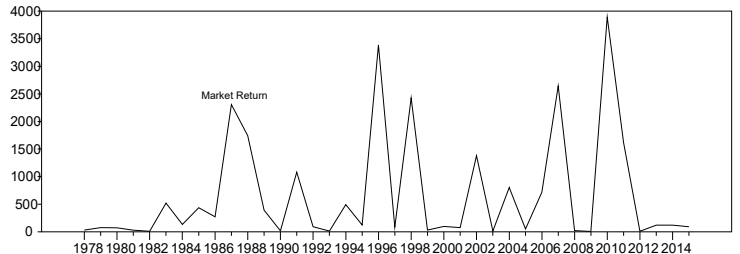

Figure 1(b): Volatility of S\&P500 index

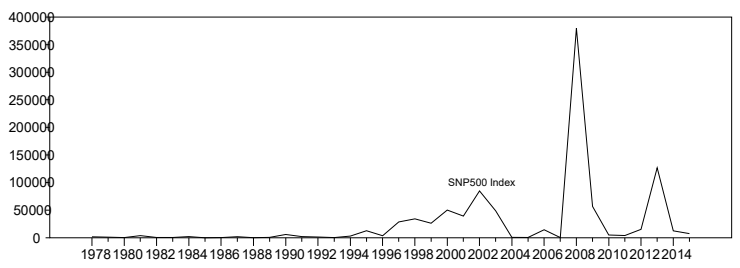

Figure 1(c): Volatility of foreign exchange rate

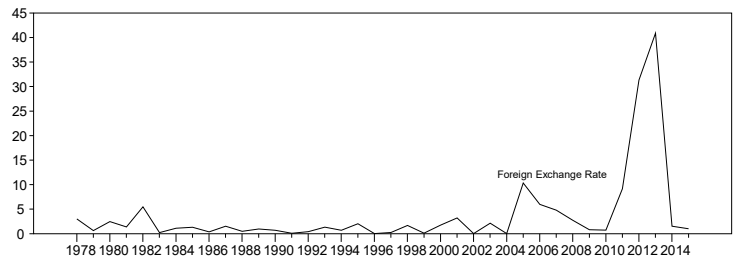

Figure 1(d): Volatility of lending interest rate

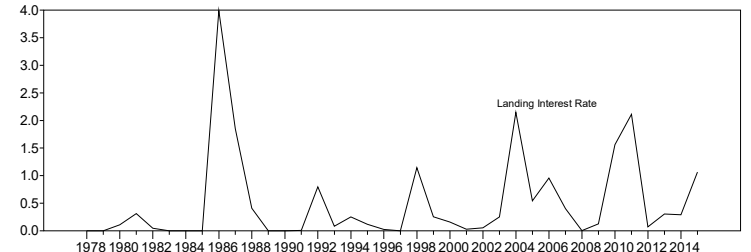

Figure 1(e): Volatility of money supply

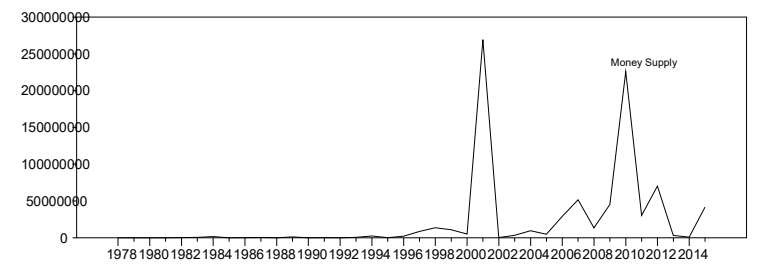

4.3 Estimation of the volatility equation: Here the following equation has been considered to estimate

$$
\begin{aligned}
& \ln \sigma_{M R E T, t}^{2}=\psi_{0}+\psi_{1} \ln \sigma_{F E R, t}^{2}+\psi_{2} \ln \sigma_{L I R, t}^{2}+\psi_{3} \ln \sigma_{M 2, t}^{2}+\psi_{4} \ln \sigma_{S N P, t}^{2}+\psi_{5} \Delta \ln P G D P_{t} \\
& +\psi_{6} \Delta \ln D I N V_{t}+\psi_{7} \Delta \ln U R_{t}+\psi_{8} \Delta \ln T L E_{t}+\psi_{9} \Delta \ln H A R_{t}+\psi_{10} \Delta \ln I N D V A_{t}+\eta_{t}
\end{aligned}
$$

At first the equation (6) has been estimated by the robust least square method for autocorrelation. Later, the stepwise method has been applied to estimate the regression equation. The results have been provided in Table- 3 and Table-4.

From the estimated result of robust least square (Table-3), it can be concluded that volatility of foreign exchange rates, the volatility of S\&P 500 index, domestic investment, and tertiary level of education have significant negative impacts on stock market return volatility where volatility or lending interest rate and per capita GDP have a significant positive impact on stock market volatility.

Table 3: Results of short run equation estimated by robust least square

\begin{tabular}{lrrr}
\hline Variables & Coefficients & t-statistic & p-value \\
\hline Constant & $7.2685^{* * *}$ & 6.6047 & 0.0000 \\
$\ln \sigma_{F E R}^{2}$ & $-0.3771^{* * *}$ & -3.5861 & 0.0003 \\
$\ln \sigma_{L I R}^{2}$ & $0.1364^{* * *}$ & 4.1101 & 0.0000 \\
$\ln \sigma_{M 2}^{2}$ & 0.0580 & 0.9570 & 0.3386 \\
$\ln \sigma_{S N P}^{2}$ & & -2.7200 & 0.0065 \\
$\Delta \ln$ PGDP & $-0.3025^{* * *}$ & 1.9810 & 0.0476 \\
$\Delta \ln$ INV & $6.1724^{* *}$ & -3.5530 & 0.0004 \\
$\Delta \ln$ UR & $-4.4608^{* * *}$ & -1.2348 & 0.2169 \\
$\Delta \ln$ TLE & -14.3004 & -5.3040 & 0.0000 \\
$\Delta \ln$ HAR & $-0.9800^{* * *}$ & -0.2038 & 0.8385 \\
$\Delta \ln$ INDVA & -0.0399 & 0.7368 & 0.4612 \\
\hline
\end{tabular}

Note: ${ }^{* * *}$ Significant at $1 \%$ level, ${ }^{* *}$ Significant at $5 \%$ level, ${ }^{*}$ Significant at $10 \%$ level. 
From the estimated results by step wise regression (Table-4), it can be concluded that interest rate volatility has significant positive impacts on stock market volatility. It can be said that fluctuation in interest rates create an opportunity for investment in the stock market. Specially, market analysts and investors who can confidently predict the interest rate movement can gain by investing in the stock market. Volatility in foreign exchange rates has a significant negative impact on stock market volatility.

Table 4: Results of short run equation estimated by step wise regression

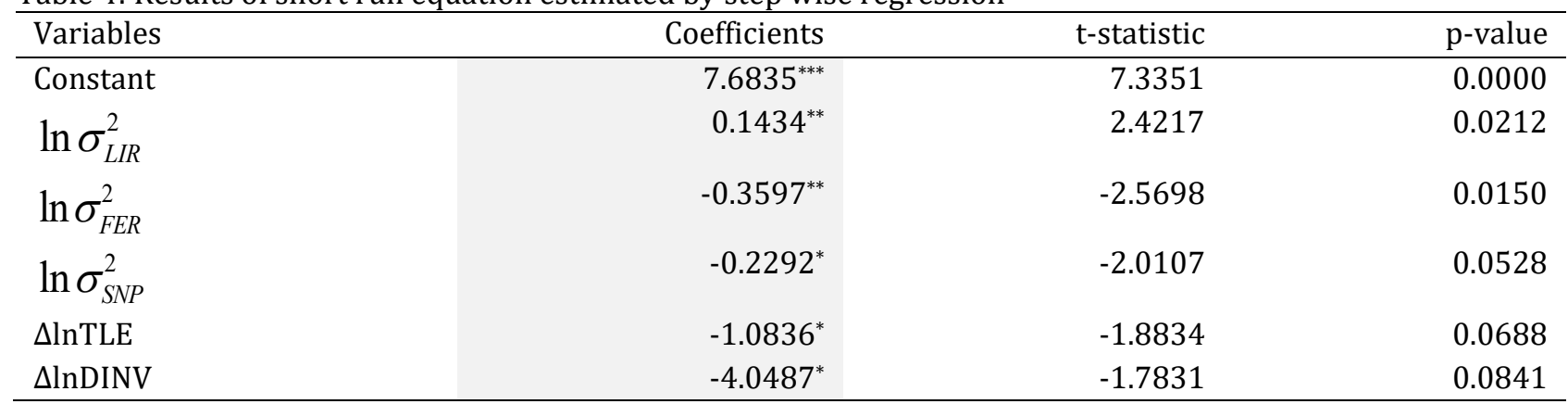

Note: ***Significant at $1 \%$ level, ${ }^{* *}$ Significant at $5 \%$ level, *Significant at $10 \%$ level.

Thus, it can be said that due to more fluctuation in foreign currency (USD), foreign investors will be more concerned about the investment in the stock market. Volatility in S \& P 500 index has a significant negative impact on the volatility of stock market returns. Therefore, more volatility in foreign markets transforms the investors in emerging economy stock market to diversify their risk. The tertiary level of education has a significant negative impact on stock market volatility. Thus, the results indicate that the higher the tertiary level of education, people will be more concerned to invest in stock market or people will prudentially judge their investment decisions. Domestic investment has a significant negative impact on stock market volatility. It can be said that firms which have long term growth opportunities usually behave in stable way. Therefore, their stocks are less sensitive to market shocks.

\subsection{Estimation of VAR model based on the variables suggested by stepwise regression}

Since there is no cointegrating relationship among the variables, only short run causality among the variables will be investigated by a multivariate pth order VAR model using the variables suggested by the step wise regression. The multivariate pth order VAR model is given below:

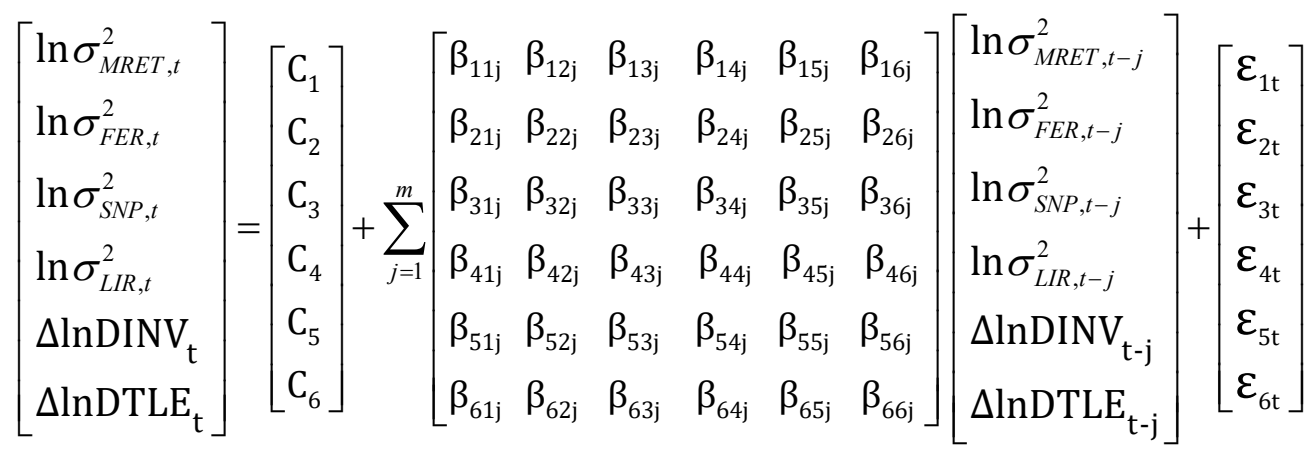

Here, C's and $\beta$ 's are the parameters to be estimated. The results of VAR model has been provided in Table-5. From the estimated results of VAR model (Table-8), it can be concluded that there is no short run causality among the variables.

Table 5: Short run causality

\begin{tabular}{l|rrrrrr} 
& $\ln \sigma_{\text {MRET }}^{2}$ & $\ln \sigma_{\text {LIR }}^{2}$ & $\ln \sigma_{\text {FER }}^{2}$ & $\ln \sigma_{S N P}^{2}$ & $\Delta \ln D I N V$ & $\Delta \operatorname{lnTLE}$ \\
$\ln \sigma_{\text {MRET }}^{2}$ & & 0.2849 & 0.0023 & 0.3403 & 0.1051 & 1.0605 \\
$\ln \sigma_{\text {LIR }}^{2}$ & & $(0.5975)$ & $(0.9623)$ & $(0.5640)$ & $(0.7480)$ & $(0.3113)$ \\
$\ln \sigma_{F E R}^{2}$ & 0.2474 & & 0.0123 & 0.3065 & 0.7792 & 0.1657 \\
& $(0.6226)$ & & $(0.9123)$ & $(0.5839)$ & $(0.3844)$ & $(0.6868)$ \\
$\ln \sigma_{S N P}^{2}$ & 0.5001 & 0.5832 & & 0.3761 & 0.0304 & 0.2637 \\
& $(0.4849)$ & $(0.4510)$ & & $(0.5443)$ & $(0.8628)$ & $(0.6114)$ \\
& 0.4023 & 0.4280 & 0.1927 & & 0.1867 & 0.0555 \\
& $(0.5307)$ & $(0.5179)$ & $(0.6639)$ & & $(0.6687)$ & $(0.8153)$ \\
\hline
\end{tabular}




\begin{tabular}{lrrrrr|r}
\hline$\Delta \ln D I N V$ & 0.2815 & 0.2379 & 0.2547 & 0.8664 & & 0.2137 \\
& $(0.5996)$ & $(0.6293)$ & $(0.6175)$ & $(0.3594)$ & & $(0.6472)$ \\
$\Delta \operatorname{lnTLE}$ & 0.0491 & 0.1300 & 0.0129 & 0.0075 & 0.0015 & \\
& $(0.8262)$ & $(0.7210)$ & $(0.9104)$ & $(0.9317)$ & $(0.9690)$ & \\
\hline
\end{tabular}

Note: ${ }^{* *}$ Significant at $1 \%$ level, ${ }^{* *}$ Significant at $5 \%$ level, ${ }^{*}$ Significant at $10 \%$ level.

\subsection{Stability test of the parameters}

Finally the stability of the parameters has been examined using cumulative sum (CUSUM) and cumulative sum of squares (CUSUMSQ) tests proposed by Borensztein et al., (1998). From the CUSUM test and CUSUM test, all values lie within the critical bounds during the estimation period. Therefore, parameters (estimated by step wise regression) are stable. The related graphs of these tests are presented in Figure-2(a) and Figure-2(b).

Figure-2(a): CUSUM test

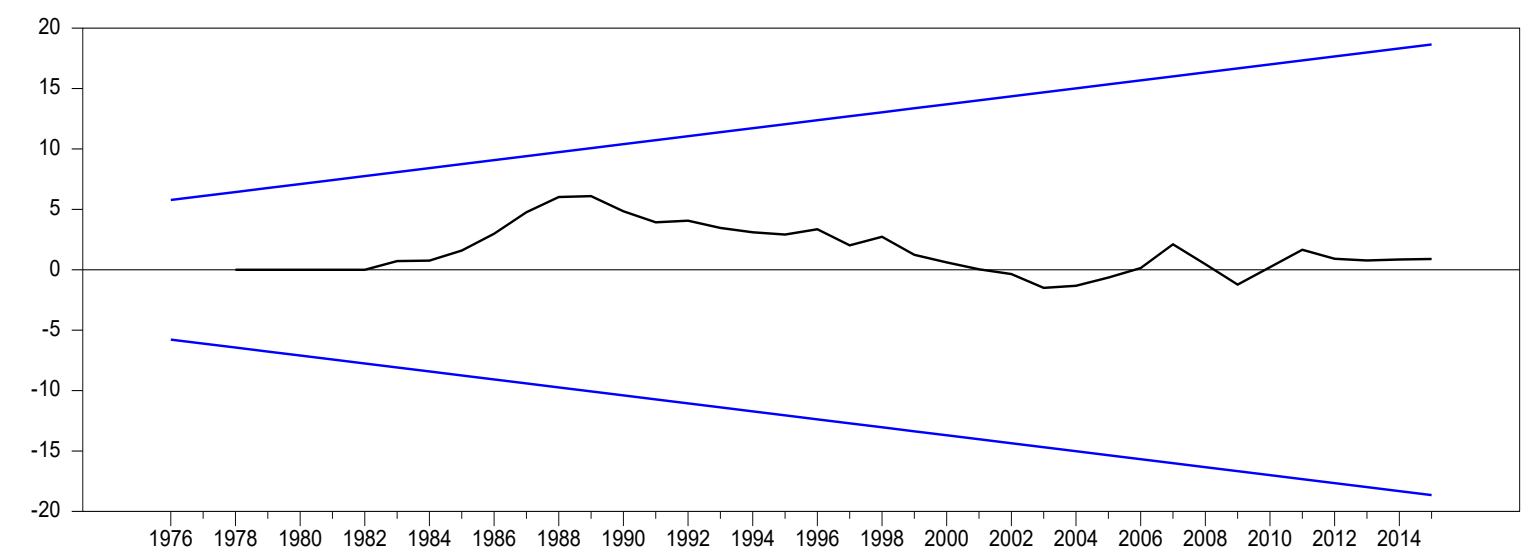

Figure-2(b): CUSUMSQ test

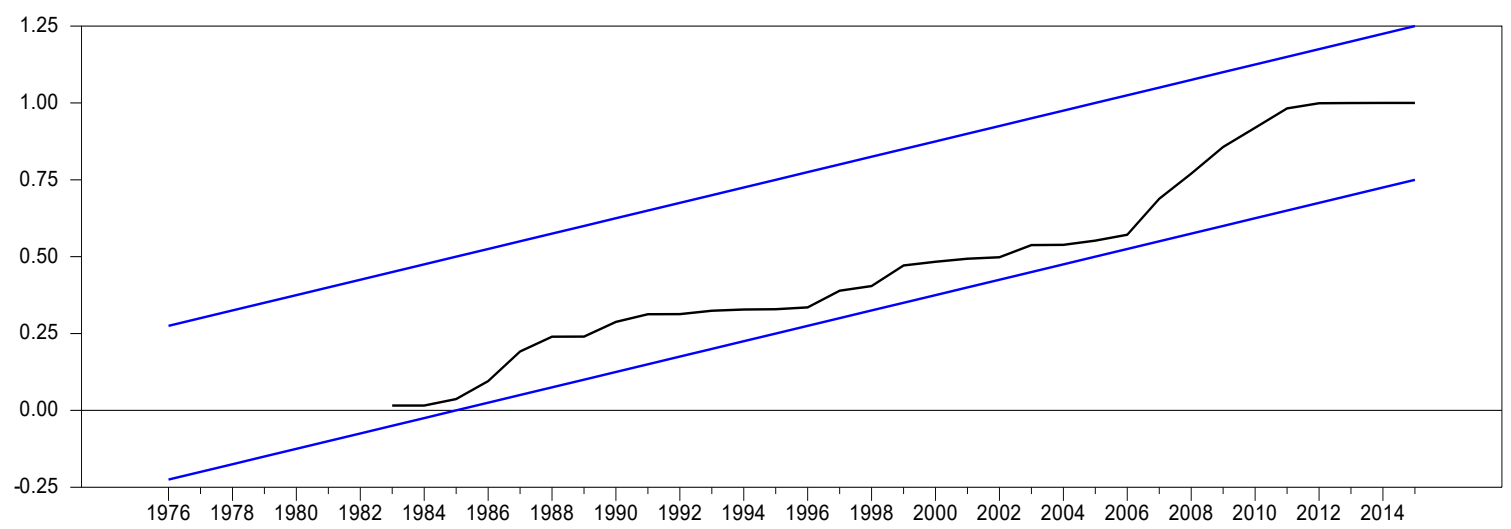

To get an overwhelming conclusion about the stability of the parameters, a joint test along with the individual test of the parameters are computed. The test results suggest that the parameters (estimated by step wise regression) are stable in all circumstances. Test results have been provided in Table-6.

Table 6: Summary of stability test

\begin{tabular}{lrr}
\hline & Test Statistic & P-value \\
\hline Joint Test & 0.9258 & 0.5100 \\
Variance & 0.1030 & 0.5500 \\
$\ln \sigma_{S N P}^{2}$ & 0.1845 & 0.2900 \\
$\ln \sigma_{F E R}^{2}$ & 0.1237 & 0.4600 \\
$\ln \sigma_{\text {LIR }}^{2}$ & 0.1453 & 0.3900 \\
$\Delta \ln$ IINV & & 0.2500 \\
$\Delta \ln T L E$ & 0.2037 & 0.4400
\end{tabular}

Note: ***Significant at $1 \%$ level, ${ }^{* *}$ Significant at $5 \%$ level, *Significant at $10 \%$ level. 


\section{Conclusion and policy implications}

The S \& P 500 index volatility, foreign exchange rate volatility, interest rate volatility, the tertiary level of education, and domestic investment have a significant impact on stock market return volatility. Lending interest rate volatility has a significant positive impact on stock market volatility. Hence, after announcing an interest rate by the country's central bank, the stock market return will be affected. Therefore, those who can accurately predict the interest rate movement can benefit from investment in the stock market. Therefore, general investors, market analysts, and fund managers should be more careful about managing interest rate risk. Since foreign exchange rate fluctuations have significant negative impacts on stock market return volatility, general investors, market analysts, and fund managers should be more concerned about foreign exchange rate fluctuation. Increases in the tertiary level of education on finance and economics will make the market more stable since investors will make prudential decisions about the investment in stock market. Therefore, to have more stable, efficient, and viable stock market, an increase in the tertiary level of education plays a big role. More industrialization will take place by increases in domestic investment. Therefore, firms who have long term growth opportunities commit more investment and their stock will behave in a stable way. Therefore, to have long term benefits form investment in stock market, general investors, market analysts, and fund managers should emphasize firms which have strong fundamentals and sustainable growth opportunities because involvement of those firms makes the market more stable. More economic growth will contribute to an upward movement of the stock market.

\section{References}

Aliyu, S. U. R. (2012). Does Inflation have an Impact on Stock Returns and Volatility? Evidence from Nigeria and Ghana. Applied Financial Economics 22 (6), 427-435. https://doi.org/10.1080/09603107.2011.617691

Ashaolu, T. O. and M. S. Ogunmuyiwa (2011). An Econometric Analysis of the Impact of Macro Economic Variables on Stock market movement in Nigeria. Journal of Business Management 3(1), 72-78.

Borensztein, E., De Gregorio, J., and J. W. Lee (1998). How does FDI affect economic growth. Journal of International Economics 45(1), 115-135. https://doi.org/10.1016/S0022-1996(97)00033-0

Chinzara, Z. (2011). Macroeconomic Uncertainty and Conditional Stock Market Volatility in South Africa. South African Journal of Economics 79(1), 27-49. https://doi.org/10.1111/j.1813-6982.2011.01262.x

Chowdhury, S. S. H., and M. A. Rahman (2004). On the Empirical Relation between Macroeconomic Volatility and Stock Market Volatility in Bangladesh. The Global Journal of Finance and Economics 1(2), 209-225.

Davis, N., and A. M. Kutan (2003). Inflation and output as predictors of stock returns and volatility: international evidence. Applied Financial Economics 13, 693-700. https://doi.org/10.1080/09603100210139429

Engle, R. F., and J. G. Rangel (2005). The Spline GARCH Model for Unconditional Volatility and its Global Macroeconomic Causes. Czech National Bank, Research Department Working Papers 2005/13

Fama, E. F. (1981). Stock returns, real activity, inflation and money. American Economic Review 7(4), 545-565.

Fama, E. F., and G. W. Schwert (1977). Asset returns and inflation. Journal of Financial Economics 5(2), 115-146. https://doi.org/10.1016/0304-405X(77)90014-9

Johansen S. and K. Juselius (1990). Maximum likelihood estimation and inference on cointegration-with application to the demand for money. Oxford Bulletin of Economics and Statistics 52, 169-210. https://doi.org/10.1111/j.1468-0084.1990.mp52002003.x

Kadir, H. B. A., Selamat, Z., Masuga, T., and R. Taudi (2011). Predictability Power of Interest Rate and Exchange Rate Volatility on Stock Market Return and Volatility: Evidence from Bursa Malaysia. International Conference on Economics and Finance Research IPEDR, Vol.4, Singapore.

Krishnamurti, C., Sequeira, J. M., and F. Fangjian (2003). Stock exchange governance and market quality. Journal of Banking and Finance 27(9), 1859-1878. https://doi.org/10.1016/S0378-4266(03)00105-5

Liljeblom, E., and M. Stenius (1997). Macroeconomic Volatility and Stock Market Volatility: Empirical Evidence on Finnish Data. Applied Financial Economics 7, 419-426. https://doi.org/10.1080/096031097333538

Morelli, D. (2002). The Relationship between Conditional Stock Market Volatility and Conditional Macroeconomic Volatility Empirical Evidence Based on UK Data. International Review of Financial Analysis 11, 101-110. https://doi.org/10.1016/S1057-5219(01)00066-7

Okoli, M. N. (2012). X-Raying the Impact of Domestic and Global Factors on Stock Return Volatility in the Nigerian Stock Market. European Scientific Journal 8 (12), 235-250.

Oseni, I. O., and P. I. Nwosa (2011). Stock Market Volatility and Macroeconomic Variables Volatility in Nigeria: An Exponential GARCH Approach. Journal of Economic and Sustainable Development 2(10), 43-53.

Pesaran, H. M. and B. Pesaran (1997). Microfit 4.0, Oxford University Press: Oxford.

Pesaran, M. H. and Y. Shin (1999). An autoregressive distributed lag modelling approach to cointegration analysis, Econometrics and Economic Theory in the 20th Century: the Ragnar Frisch Centennial Symposium, Cambridge University Press: Cambridge.

Pesaran, M.H., Shin, Y. and R.J. Smith (2001). Bounds testing approaches to the analysis of level relationships. Journal of Applied Econometrics 16, 289-326. https://doi.org/10.1002/jae.616

Schwert, W. G. (1989). Why does stock market volatility change over time? Journal of Finance 44, 1368-1388. https://doi.org/10.1111/j.1540-6261.1989.tb02647.x 
Wei, Y. (2005). The Development of the Securities Market and Regulation in China. The Loyola of Los Angeles International and Comparative Law Review (ILR) 27(3), 479-514.

Yaya, O. S. and O. I. Shittu (2010). On the Impact of Inflation and Exchange Rate on Conditional Stock Market Volatility: A Reassessment. American Journal of Scientific and Industrial Research 1 (2), 115-117. https://doi.org/10.5251/ajsir.2010.1.2.115.117

Zakaria, Z. and S. Shamsuddin (2012). Empirical Evidence on the Relationship between Stock Market Volatility and Macroeconomics Volatility in Malaysia. Journal of Business Studies Quarterly, 4 (2), 61-71.

\section{Appendix}

Table 1: Unit root test results at level form

\begin{tabular}{|c|c|c|c|c|}
\hline \multicolumn{5}{|c|}{ Model with constant term [Level Form] } \\
\hline Variables & ADF test & P-value & PP test & P-value \\
\hline MRET & $-4.2562^{* * *}$ & 0.0018 & $-4.2562^{* * *}$ & 0.0018 \\
\hline $\operatorname{lnDINV}$ & -0.1829 & 0.9321 & -0.7991 & 0.8082 \\
\hline FER & 0.0365 & 0.9563 & 0.4180 & 0.9813 \\
\hline SNP500 & 0.1430 & 0.9651 & 0.1363 & 0.9646 \\
\hline $\operatorname{lnUR}$ & -0.5020 & 0.8796 & $-3.2131^{* *}$ & 0.0267 \\
\hline M2 & 35.1956 & 0.9999 & 30.2909 & 0.9999 \\
\hline $\operatorname{lnHAR}$ & $-4.0606^{* * *}$ & 0.0030 & $-4.1509^{* * *}$ & 0.0024 \\
\hline $\ln P G D P$ & 0.6453 & 0.9892 & 0.6000 & 0.9880 \\
\hline LIR & -2.1451 & 0.2290 & -1.6252 & 0.4605 \\
\hline $\operatorname{lnTLE}$ & -1.0777 & 0.7150 & -1.0777 & 0.7150 \\
\hline lnINDVA & -1.4623 & 0.5415 & -1.7875 & 0.3810 \\
\hline \multicolumn{5}{|c|}{ Model with constant and trend term [Level Form] } \\
\hline Variables & ADF test & P-value & PP test & P-value \\
\hline MRET & $-4.1936^{* *}$ & 0.0105 & $-4.1936^{* *}$ & 0.0105 \\
\hline $\ln \mathrm{DIV}$ & -1.5691 & 0.7865 & -3.0125 & 0.1419 \\
\hline FER & -3.7705 & 0.0294 & -2.9916 & 0.1474 \\
\hline SNP500 & -2.9771 & 0.1516 & -2.5138 & 0.3202 \\
\hline $\operatorname{lnUR}$ & $-3.6056^{* *}$ & 0.0434 & $-6.9905^{* * *}$ & 0.0000 \\
\hline M2 & 19.7191 & 1.0000 & 17.7484 & 1.0000 \\
\hline $\operatorname{lnHAR}$ & -0.3762 & 0.5589 & -0.6913 & 0.4091 \\
\hline lnPGDP & -1.0362 & 0.9268 & -1.0362 & 0.9268 \\
\hline LIR & -2.0832 & 0.5383 & -1.6980 & 0.7331 \\
\hline $\operatorname{lnTLE}$ & -1.4328 & 0.8307 & -2.4098 & 0.3591 \\
\hline lnINDVA & -3.7263 & 0.0325 & -2.9008 & 0.1733 \\
\hline \multicolumn{5}{|c|}{ Model without constant and trend term [Level Form] } \\
\hline Variables & ADF test & P-value & PP test & P-value \\
\hline MRET & $-3.2836^{* * *}$ & 0.0017 & $-3.2723^{* * *}$ & 0.0017 \\
\hline $\operatorname{lnDINV}$ & 1.7771 & 0.9799 & 1.2853 & 0.9471 \\
\hline FER & 4.3779 & 1.0000 & 4.3198 & 1.0000 \\
\hline SNP500 & 1.5997 & 0.9711 & 1.6243 & 0.9725 \\
\hline $\ln U R$ & 2.4228 & 0.9954 & 4.4524 & 1.0000 \\
\hline M2 & 43.5395 & 0.9999 & 37.3309 & 0.9999 \\
\hline $\operatorname{lnHAR}$ & -0.3435 & 0.5547 & -0.6711 & 0.4199 \\
\hline lnPGDP & 4.5698 & 1.0000 & 4.4006 & 1.0000 \\
\hline LIR & -0.0437 & 0.6621 & -0.0437 & 0.6621 \\
\hline $\operatorname{lnTLE}$ & 2.5287 & 0.9962 & 0.8916 & 0.8969 \\
\hline lnINDVA & 3.1396 & 0.9993 & 9.2530 & 1.0000 \\
\hline
\end{tabular}

Note: ${ }^{* * *}$ Significant at $1 \%$ level, ${ }^{* *}$ Significant at $5 \%$ level, ${ }^{*}$ Significant at $10 \%$ level.

Table 2: Unit root test results at first difference form

Model with constant term [Difference Form]

\begin{tabular}{lcccc}
\hline Variables & ADF test & P-value & PP test & P-value \\
\hline$\Delta \ln$ DINV & $-9.1055^{* * *}$ & 0.0000 & $-9.1165^{* * *}$ & 0.0000 \\
\hline
\end{tabular}




\begin{tabular}{|c|c|c|c|c|}
\hline$\Delta \mathrm{FER}$ & $-4.7383^{* * *}$ & 0.0005 & $-7.6732^{* * *}$ & 0.0000 \\
\hline$\Delta$ SNP500 & $-5.2839^{* * *}$ & 0.0001 & $-5.2359^{* * *}$ & 0.0001 \\
\hline$\Delta \ln U R$ & $-3.6402^{* * *}$ & 0.0095 & $-3.7543^{* * *}$ & 0.0070 \\
\hline$\Delta \mathrm{M} 2$ & $-5.3991^{* * *}$ & 0.0001 & $-6.6311^{* * *}$ & 0.0000 \\
\hline$\Delta \operatorname{lnHAR}$ & $-9.3996^{* * *}$ & 0.0000 & $-9.3996^{* * *}$ & 0.0000 \\
\hline$\Delta \ln P G D P$ & $-5.3707^{* * *}$ & 0.0001 & $-5.3707^{* * *}$ & 0.0001 \\
\hline$\Delta \mathrm{LIR}$ & $-4.1311^{* * *}$ & 0.0025 & $-3.9988^{* * *}$ & 0.0038 \\
\hline$\Delta \operatorname{lnTLE}$ & $-3.8238^{* * *}$ & 0.0067 & $-5.8931^{* * *}$ & 0.0000 \\
\hline$\Delta \operatorname{lnINDVA}$ & $-3.6776^{* * *}$ & 0.0085 & $-3.7123^{* * *}$ & 0.0078 \\
\hline \multicolumn{5}{|c|}{ Model with constant and trend term [Difference Form] } \\
\hline Variables & ADF test & P-value & PP test & P-value \\
\hline$\Delta \operatorname{lnDINV}$ & $-9.0654^{* * *}$ & 0.0000 & $-9.0654^{* * *}$ & 0.0000 \\
\hline$\Delta \mathrm{FER}$ & $-4.5718^{* * *}$ & 0.0043 & $-7.4102^{* * *}$ & 0.0000 \\
\hline$\Delta$ SNP500 & $-5.3150^{* * *}$ & 0.0005 & $-5.2470^{* * *}$ & 0.0007 \\
\hline$\Delta \ln U R$ & $-3.6983^{* * *}$ & 0.0091 & $-3.7141^{* * *}$ & 0.0069 \\
\hline$\Delta \mathrm{M} 2$ & $-7.3279^{* * *}$ & 0.0000 & $-7.1819^{* * *}$ & 0.0000 \\
\hline$\Delta \operatorname{lnHAR}$ & $-9.3074^{* * *}$ & 0.0000 & $-9.3074^{* * *}$ & 0.0000 \\
\hline$\Delta \operatorname{lnPGDP}$ & $-5.3108^{* * *}$ & 0.0005 & $-5.3108^{* * *}$ & 0.0005 \\
\hline$\Delta \mathrm{LIR}$ & $-4.2564^{* * *}$ & 0.0091 & $-4.0515^{* *}$ & 0.0151 \\
\hline$\Delta \operatorname{lnTLE}$ & $-4.0858^{* *}$ & 0.0159 & $-5.8103^{* * *}$ & 0.0000 \\
\hline$\Delta \operatorname{lnINDVA}$ & $-3.8523^{* *}$ & 0.0243 & $-3.8522^{* *}$ & 0.0243 \\
\hline \multicolumn{5}{|c|}{ Model without constant and trend term [Difference Form] } \\
\hline Variables & ADF test & P-value & PP test & P-value \\
\hline$\Delta \ln D I N V$ & $-8.6726^{* * *}$ & 0.0000 & $-8.5563^{* * *}$ & 0.0000 \\
\hline$\triangle \mathrm{FER}$ & $-6.1302^{* * *}$ & 0.0000 & $-3.4752^{* * *}$ & 0.0010 \\
\hline$\Delta$ SNP500 & $-4.9348^{* * *}$ & 0.0000 & $-4.9348^{* * *}$ & 0.0000 \\
\hline$\Delta \ln U R$ & $-2.6536^{* * *}$ & 0.0094 & $-2.8128^{* * *}$ & 0.0062 \\
\hline$\Delta \mathrm{M} 2$ & $-7.6362^{* * *}$ & 0.0000 & $-4.7133^{* * *}$ & 0.0000 \\
\hline$\Delta \ln H A R$ & $-9.4780^{* * *}$ & 0.0000 & $-9.4780^{* * *}$ & 0.0000 \\
\hline$\Delta \ln P G D P$ & $-3.6592^{* * *}$ & 0.0006 & $-3.8159^{* * *}$ & 0.0003 \\
\hline$\Delta \mathrm{LIR}$ & $-4.1972^{* * *}$ & 0.0001 & $-4.0712^{* * *}$ & 0.0002 \\
\hline$\Delta \operatorname{lnTLE}$ & $-5.8082^{* * *}$ & 0.0000 & $-5.8082^{* * *}$ & 0.0000 \\
\hline$\Delta \operatorname{lnINDVA}$ & $-4.3877^{* * *}$ & 0.0021 & $-5.8133^{* * *}$ & 0.0000 \\
\hline
\end{tabular}

Note: ${ }^{* * *}$ Significant at $1 \%$ level, ${ }^{* *}$ Significant at $5 \%$ level, *Significant at $10 \%$ level.

Table 3: Unit root test results of volatility

\begin{tabular}{|c|c|c|c|c|}
\hline \multicolumn{5}{|c|}{ Model with constant term [Level Form] } \\
\hline Variables & ADF test & P-value & PP test & P-value \\
\hline $\ln \sigma_{M R E T}^{2}$ & $-6.8952^{* * *}$ & 0.0000 & $-6.9856^{* * *}$ & 0.0000 \\
\hline $\ln \sigma_{F E R}^{2}$ & $-5.8268^{* * *}$ & 0.0000 & $-5.8537^{* * *}$ & 0.0000 \\
\hline $\ln \sigma_{L I R}^{2}$ & $-4.0023^{* * *}$ & 0.0037 & $-3.8114^{* * *}$ & 0.0061 \\
\hline $\ln \sigma_{M 2}^{2}$ & $-2.7629^{*}$ & 0.0740 & $-2.6186^{*}$ & 0.0984 \\
\hline $\ln \sigma_{S N P}^{2}$ & $-3.9261^{* * *}$ & 0.0045 & $-4.0588^{* * *}$ & 0.0032 \\
\hline \multicolumn{5}{|c|}{ Model with constant and trend term [Level Form] } \\
\hline Variables & ADF test & P-value & PP test & P-value \\
\hline $\ln \sigma_{M R E T}^{2}$ & $-4.1694^{* *}$ & 0.0131 & $-6.8835^{* * *}$ & 0.0000 \\
\hline $\ln \sigma_{F E R}^{2}$ & $-6.0310^{* * *}$ & 0.0001 & $-6.0310^{* * *}$ & 0.0001 \\
\hline $\ln \sigma_{L I R}^{2}$ & $-8.1657^{* * *}$ & 0.0000 & $-5.5489^{* * *}$ & 0.0003 \\
\hline $\ln \sigma_{M 2}^{2}$ & $-5.0618^{* * *}$ & 0.0011 & $-5.0370^{* * *}$ & 0.0012 \\
\hline
\end{tabular}




\begin{tabular}{|c|c|c|c|c|}
\hline $\ln \sigma_{S N P}^{2}$ & $-5.1392^{* * *}$ & 0.0009 & $-5.1286^{* * *}$ & 0.0009 \\
\hline \multicolumn{5}{|c|}{ Model without constant and trend term [Level Form] } \\
\hline Variables & ADF test & P-value & PP test & P-value \\
\hline $\ln \sigma_{M R E T}^{2}$ & $-5.6375^{* *}$ & 0.0000 & $-6.9486^{* * *}$ & 0.0000 \\
\hline $\ln \sigma_{F E R}^{2}$ & $-5.9015^{* * *}$ & 0.0000 & $-5.9242^{* * *}$ & 0.0000 \\
\hline $\ln \sigma_{L I R}^{2}$ & $-2.3714^{* *}$ & 0.0194 & $-3.6916^{* * *}$ & 0.0005 \\
\hline $\ln \sigma_{M 2}^{2}$ & $-5.9331^{* * *}$ & 0.0000 & $-7.2001^{* * *}$ & 0.0000 \\
\hline $\ln \sigma_{S N P}^{2}$ & $-6.1943^{* * *}$ & 0.0000 & $-8.9111^{* * *}$ & 0.0000 \\
\hline
\end{tabular}

Note: ${ }^{* *}$ Significant at $1 \%$ level, ${ }^{* *}$ Significant at $5 \%$ level, *Significant at $10 \%$ level. 